\title{
COMMUNICATIVE INFLUENCE IN ENGLISH IDEATION DISCOURSE: RESPONSIVE STRATEGIES (BASED ON TED INTERNET PLATFORM)
}

\author{
Darya Kaysina ${ }^{1}$
}

\begin{abstract}
The article focuses on identification and description of the responsive strategies realized by the subjects of English ideation discourse. The term English ideation discourse encompasses a process and result of the communicants' interaction in the social-cultural context of a public speech. The subjects of such a discourse are the ideator and the recipient(-s) who take part in the cognitive-communicative activity in order to accept and apply the idea that is the object of this interaction. The idea refers to a mental structure translated into verbal and non-verbal means of communication. The ideator's global socially relevant communicative aim is to exert communicative influence on the recipients, so that they will put the idea into social action. This aim is achieved through the initial communicative strategies of informing, persuading and instructing that govern the sub-strategies: informative, informative-persuasive, persuasive, persuasive-instructive, and instructive. Sub-strategies are aimed at different spheres of the recipients' consciousness - rational reasoning (informative, informative-persuasive), emotions (persuasive), volition (instructive) or at the subconsciousness (persuasive-instructive). Responsive communicative actions of the recipients are divided into instant (verbal: exclamations, short answers; non-verbal: laughter, applause, gestures) and delayed (verbal: rating an ideation speech by choosing three out of fourteen available adjectives of positive / negative evaluation; non-verbal: general and average monthly number of views of the video recording of an ideation speech). The study is pioneering a systematic cognitive-communicative methodology which reveals constitutive features of a new object of linguistic analysis - English ideation discourse - and provides the tool of inferential analysis to identify and describe rational, emotional, volitional communicative influence with relevant to this influence responsive strategies that are exerted by the subjects of the ideation discourse and are manifested in their verbal and non-verbal actions.
\end{abstract}

Key words

Communicative influence, emotions, English ideation discourse, initial strategy, rational reasoning, responsive strategy, volition.

\section{Introduction}

Communicative influence and communication itself have received considerable scholarly attention in recent years. However, the main challenge faced by many researchers is the inability to track and analyse the recipients' feedback and, therefore, the inability to verify success or failure of communicative influence. Remarkably little research has gathered reliable and accurate information in order to discover what contributes to communicative influence success or, vice versa, prevents it. Nevertheless, an adequate study of communication is not possible without taking into consideration how the recipient comprehends certain information, how they react to the speaker's certain strategies. Study of the recipient's responsive actions can prove for the fact success or failure of some communicative strategies or tactics used by the speaker and success or failure of the communication as a whole.

The object of the thesis is responsive communicative actions by the recipients of English ideation speeches, and the subject is their semiotic interpretation in the interactive context of communicative interaction of the ideation discourse subjects.

The purpose of the thesis focuses on identification and description of the responsive strategies as

\footnotetext{
1 Darya Kaysina, V. N. Karazin Kharkiv National University, 4 Svobody Sq., Kharkiv, 61022, Ukraine, e-mail: darya.kaysina@karazin.ua ORCID ID 0000-0003-3191-2435
}

a reaction to communicative influence of the initial strategies realised by the subjects of English ideation discourse. It is necessary here to clarify exactly what is meant by ideation discourse. Ideation as a term was introduced in Husserl's phenomenology as a kind of direct non-sensuous seeing that takes place at the level of intellection and is directed at universals or essences (Гуссерль 2001, 325, 634). In surveys of psychology Vygotsky (Выгосткий 1999, 78-84) has shown that ideation is the capacity to operate on the basis of non-actual or absent stimuli. In marketing and PR-technologies the term 'ideation' is used to describe creative process of generating, development and spreading new ideas, where idea is a basic element of a though that can be imagined visually, clearly formulated or be abstract (Graham, Bachmann, 2004, 54).

In this research functional interpretation of discourse is taken following Kharkiv linguistic school (Как нарисовать портрет птицы, 2017). Shevchenko (Шевченко 2016) defines it is a multifaceted cognitive-communicative-language system-gestalt combining cognitive, social-pragmatic and linguistic aspects. Cognitive aspect is sense building, formation of ideas and beliefs; social-pragmatic aspect contains communicants' interaction in certain social-cultural context and situation; linguistic aspect is expressed in using verbal and paraverbal semiotic systems.

This research suggests that English ideation discourse is defined as a process and result of the communicants' interaction in the social-cultural context of 
a public speech (social-pragmatic aspect), where the object of the interaction is an idea as a mental structure translated into verbal and non-verbal means of communication (semiotic aspect, including linguistic aspect), and the subjects are the ideator and the recipient(-s) who are engaged in the cognitive-communicative activity which results in acceptance or rejection of the idea (cognitive aspect).

\section{Methodology}

English ideation discourse is initiated by a speech given by a participant of a conference organised by TED - a global non-profit community, the main goal of which is to spread ideas. This goal is reflected in the TED motto "ideas worth spreading". The goal of TED community is primarily reached by holding conferences where speakers deliver short (up to 18 minutes) speeches in English. Each speech suggests an idea that can solve an urgent problem (Anderson, 2016). The conference name "Technology, Entertainment and Design" depicts only basic topics that the community takes interest in. The whole list includes about includes 438 topics (Addiction, Biotech, Dark matter, Ebola, Immigration, Marine biology, Nuclear energy, Pandemic, Religion, Slavery, Terrorism, Youth etc.) (TED, 2019). TED community tends to increase the scope of their activity in different fields simultaneously, especially in means of "spreading the ideas", i.e. ways of delivering the content to the recipients. The main arteria of spreading the ideas around the world is TED Internet platform, designed specifically for this purpose. In this thesis TED conference participants' talks are called ideation speeches, and the speakers are called ideators. Video recordings of ideation speeches are published on TED Internet platform and they become available for the public who can watch them and rate them using a list of qualitative characteristics verbalised by English evaluative adjectives. This list is provided by the content managers of TED Internet platform. In such a way the recipients become subjects of ideation discourse. The research data come from the video recordings of 202 ideation speeches, manifesting the ideator's initial communicative influence strategies, and 4 types of reactions to them representing the recipients' responsive strategies.

Methodologically the research rests on the cognitive-communicative approach to language analysis where linguistic meaning is addressed as a dynamic cognitive structure that is being construed in an act of communication.

The data are put to inferential analysis of the communicative actions of the subjects of English ideation discourse to reveal the ideator's presuppositions and the recipients' inferences which are made while they are realising their strategic communicative goals in certain spatiotemporal coordinates focusing attention on the same object / referent and which are translated into their verbal and non-verbal communicative actions.
The unit of cognitive analysis of communicative influence in English ideation discourse is inter-subjective act that is "an inter-action, structurally including at least two verbal or / and co-verbal utterances: one initial and the other responsive, embedded in the complex dynamic psychic experiential context 'shared' by the communicants focusing attention on the same verbal / co-verbal utterance as a perceptual stimulus which triggers parallel conscious / nonconscious inference processes involving cognition, volition, and affect to issue a command of a meaningful goal-oriented communicative and / or (immediate or postponed) social action" (Martynyuk 2017, 65-66).

\section{Results and discussion}

The central thesis is that ideation communicative influence is initiated by the ideator's verbal and non-verbal communicative actions, intended to inform and / or persuade the recipients that the problem raised in the speech is urgent / the idea suggested in the speech is valuable and motivate the recipients to put the idea into practice. The role of the recipients in a dialogue interaction does not only involve passive comprehension. On the contrary, it always presupposes responsive action (Бахтин 1979, 246-247). As soon as the ideation speech begins the recipient starts to comprehend and conceive the problem and idea, and to take certain responsive (furthermore, social) actions in order to accept the idea, implement it or to reject it. Whereas the recipients use verbal and / or non-verbal responsive strategies in order to give the feedback regarding the idea itself, the ideation talk as a whole or a certain part of it / a certain action by the ideator.

The ideator's global socially relevant communicative aim is to exert communicative influence on the recipients, so that they will put the idea into social action. This aim is achieved through the communicative strategies of informing, persuading and instructing that govern the sub-strategies: informative, informative-persuasive, persuasive, persuasive-instructive, and instructive. Ideation communicative influence is aimed at different spheres of the recipients' consciousness - rational reasoning, emotions, volition - and subconsciousness. The communicative influence exerted by these strategies is characterized by the sphere of the consciousness that is being targeted by any of them. Rational reasoning is affected by informative and informative-persuasive sub-strategies, sphere of emotions experiences communicative influence with persuasive sub-strategy, volition is influenced with instructive sub-strategy. Target of persuasive-instructive sub-strategy is not consciousness, but subconsciousness, however impact on subconsciousness will be not in the scope of this article.

To determine which sphere of consciousness is influenced by the ideator's communicative strategy is relevant for this study because in such a way it becomes possible to correlate the ideator's initial and the recip- 
ient's responsive strategies. In the ideation discourse communicative success of ideation influence can be assessed through analysis of verbal and non-verbal responsive communicative actions of the recipients.

Responsive communicative actions of the recipients are divided into instant and delayed, both of these categories are additionally classified according to their way of realization: verbal or non-verbal. Instant verbal responsive communicative actions include:

1) exclamations of the recipients during the ideation speech: And look, I know it's weird having an English person standing here before you talking about all this. All I can say is: I care. I'm a father, and I love this country. And I believe truly, actually, that if change can be made in this country, beautiful things will happen around the world. If America does it, other people will follow. It's incredibly important. (Audience) Yeah! (Applause) (Oliver, 2010)

2) short answers as a response to the ideator's question or address to the audience: So, think about your own life, the decisions that have shaped your destiny. And that sounds really heavy, but in the last five or 10 years, have there been some decisions that if you'd made a different decision, your life would be completely different? How many can think about it? Better or worse. Say, "Aye." (Audience) Aye. (Robbins, 2006)

Instant non-verbal responsive strategies are laughter, applause and certain gestures, all of them are used by the audience for expressing their attitude to what is going on the stage.

Applause is a well-known sigh of approval, of accepting something or somebody. For instance, Hugh Herr (Herr, 2014) receives the audience's sign of appreciation in applause several times throughout his ideation speech. In support of his idea "Modern technologies can overcome incapability and let a person with a disability live without any limitations" the ideator shows the abilities of his own bionic legs live in front of the audience. The same experience of a woman with prosthetic bionic legs is shown on the video for the recipients, that is the evidence of an additional source of communicative influence means of multimodality (video recording). In the both cases the recipients express their admiration applauding. Judging by the video footage and the transcript, the ideator has not expected the applause, that is why he continues his speech when the audience interrupts him with a round of applause, that makes him start his passage from the very beginning. This passage causes another round of applause:

Next week, I'm visiting the Center -- (Applause) Thank you. Thank you. (Applause) Thank you. Next week I'm visiting the Center for Medicare and Medicaid Services, and I'm going to try to convince CMS to grant appropriate code language and pricing, so this technology can be made available to the patients that need it. (Applause) Thank you. (Applause) (Herr, 2014).
This fragment and the recipients' reaction to it prove that such a way of the idea implementation is well-approved by the audience, they support the ideator's aspirations and respect his achievements.

In a similar way the audience reacts to the words by Sir Ken Robinson when he almost at very beginning of his speech introduces the idea: "Creativity should be treated as seriously as literacy in education":

So I want to talk about education and I want to talk about creativity. My contention is that creativity now is as important in education as literacy, and we should treat it with the same status. (Applause) Thank you. (Applause) That was it, by the way. Thank you very much. (Laughter) So, 15 minutes left. (Laughter) Well, I was born... No. (Laughter) (Robinson, 2006)

As the audience starts to applaud at the $3^{\text {rd }}$ minute of the talk out of 18-minute time slot dedicated to it, the ideator uses this situation to change the key of the speech to the humorous one. He looks surprised and pleased that the idea has already been approved by the recipients, it has been already accepted, that his job here is done (That was it, by the way. Thank you very much). Inconguity between the ideator's behaviour and lingua-ethological norms (Мартынюк 2008) causes laughter. The humour of the situation even increases when the ideator acts as if he has remembered that he has to continue his speech for 15 more minutes and starts to tell his biography in order to fill in the rest of the time. The recipients start to laugh again.

It is important to emphasize that such responsive actions prove that the recipients definitely take part in the ideation process. They interact with the ideator by answering questions / requests / propositions. The audience supports the ideator's decision to change the serious key of the speech to a humorous one and back, this support is expressed in laughter. Both the ideator and the researcher understand it from the recipients' laughter. With instant responsive strategies the audience expresses their positive attitude not only to the ideator and to the idea in general, but specifically to explicit / implicit proposition of ways to implement the idea, explicit / implicit explanation of the reasons to put the idea into practice etc. (Kaysina, 2018, 196-207). Such a committed active audience becomes more inclined to accept the idea and further to apply it.

One of the proofs that instant reactions of the recipients are relevant and important for this study is that these reactions find their place in the official transcript of the ideation speech that is also available on TED Internet platform. For the research these reactions are of utmost importance due to the fact that the audience at TED conference is not 'generous' with their praise by way of instant responsive actions. Presence of these reactions during the ideation speech is the sign of successful ideation speech and successful ideation process. 
Delayed responsive communicative actions can be studied using the access to all the relevant information on TED Internet platform. After watching a certain ideation speech, the recipient can rate this talk using the specially organised form that contains fourteen adjectives of positive / negative evaluation. Using this form the recipient can choose from one to three qualitative adjectives. In such a way the recipients can mark the ideation speech with a certain characteristic that describes the ideation speech in the best way. Therefore, rating an ideation speech is a delayed verbal responsive strategy.

The qualitative adjectives are inspiring, persuasive, fascinating, jaw-dropping, beautiful, courageous, informative, ingenious, funny, OK, unconvincing, obnoxious, confusing, long-winded. The definitive analysis of these adjectives allows to determine which sphere of consciousness (rational, emotional and / or volitional) has to a greater degree 'experienced communicative influence'. Obviously, such a division depending on the aim at certain spheres of consciousness is rather conventional: this influence is exerted in gestalt, as can be seen from the results of the inference analysis given in the description of the ideator's speech fragments. Nonetheless, it has been assumed that if the recipient chooses adjectives informative, ingenious, courageous, OK, unconvincing, confusing to describe the ideation speech, this choice is the sign that the ideation speech has urged the recipient to rational thinking, critical analysis of the received information. Choice of fascinating, jaw-dropping, beautiful, obnoxious proves the significance of the emotional impact. Using adjective longwinded to characterize the ideation talk means that not only rational thinking has been activated, but also emotions, because this adjective is stylistically marked and it contains a metaphor. Adjectives inspiring, persuasive show that the ideation speech has exerted communicative influence not only on emotional state of the recipient, but also on volition. Regarding adjective funny, it is assumed to express influence made on all the three spheres of consciousness, as it is believed that all the spheres of consciousness take part in comprehending and understanding a humorous stimulus.

Therefore, using the definitive analysis of the characteristics and inference analysis it is possible to understand influence on which spheres of consciousness these characteristics reveal (table 1).

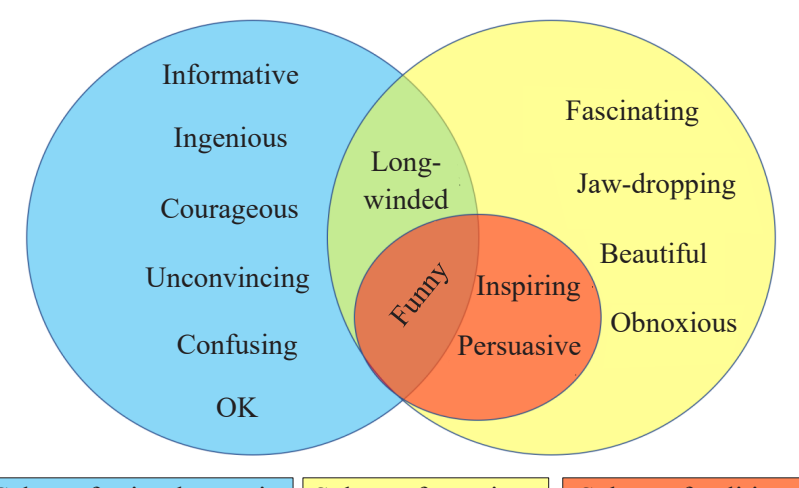

\begin{tabular}{l|l|l|}
\hline Sphere of rational reasoning & Sphere of emotions & Sphere of volition
\end{tabular}

Fig. 1. Evaluative adjectives for the ideation speech rating in accordance with the sphere of consciousness

Delayed non-verbal responsive actions include general and average monthly number of views of the video recording of an ideation speech. Every video of the TED talk is published on the Internet platform with an indication of the total number of views. Still average monthly number of views can be calculated using the formula based on the general number of views and number of months the recording has been on TED Internet platform. Both criteria are equally relevant to distinguish absolutely communicative-

Table 1

Evaluative adjectives for the ideation speech rating in accordance with the sphere of consciousness

\begin{tabular}{|l|l|l|}
\hline \multicolumn{1}{|c|}{ Characteristics } & \multicolumn{1}{|c|}{ Definition } & \multicolumn{1}{c|}{$\begin{array}{c}\text { Sphere of consciousness } \\
\text { that experiences influence }\end{array}$} \\
\hline Inspiring & exciting, encouraging & emotions \& volition \\
\hline Persuasive & making somebody agree to do or believe something & emotions \& volition \\
\hline Fascinating & extremely interesting & emotions \\
\hline Jaw-dropping & very surprising & emotions \\
\hline Beautiful & very pleasant & emotions \\
\hline Courageous & brave, able to do something without fear & rational reasoning \\
\hline Informative & giving a lot of information & rational reasoning \\
\hline Ingenious & involving new ideas & rational reasoning \\
\hline Funny & making you laugh, strange & rational reasoning \& emotions \& volition \\
\hline OK & $\begin{array}{l}\text { satisfactory but not extremely good; for showing that } \\
\text { you agree with something }\end{array}$ & rational reasoning \\
\hline Unconvincing & not seeming true or real; not capable of persuading you & rational reasoning \\
\hline Confusing & difficult to understand, unclear & rational reasoning \\
\hline Obnoxious & very unpleasant, offensive & emotions \\
\hline Longwinded & too long and therefore boring & rational reasoning \& emotions \\
\hline
\end{tabular}


ly successful ideation speeches. For that purpose, the research material (202 ideation speeches) has been selected and sorted out on the basis of these two criteria separately, on general number of views (from 10 million views) and average monthly views (from 350 thousand views per month). On comparing two selections it was found that 8 ideation speeches appeared to be in the both selections, i.e. these speeches have a considerable number of views in total and views per month. Consequently, these 8 ideation speeches are absolutely communicatively successful ideation speeches.

Based on the quantitative analysis of the percentage share of votes given to a certain characteristics of the ideation speech and mathematical treatment of the data, the current study has determined the intensity of the communicative influence and divided into irrelevant (to $15 \%$ ), moderate (from $15 \%$ to $32 \%$ ), strong (from $33 \%$ to $50 \%$ ) and dominant (from $51 \%$ to $100 \%)$.

The analysis of the absolutely communicatively successful ideation speeches has not revealed any typical set of the ideator's initial strategies that would ensure communicative success of the ideation speech. However, it was possible to reveal certain tendencies:
1) The most common characteristic for absolutely communicatively successful ideation speeches is inspiring, that expresses communicative impact made on emotional-volitional sphere of consciousness. This trend corresponds with the ideator's global socially relevant communicative aim - to put the idea into social practice, because this trend illustrates urging to volitional acts on the basis of emotional contamination. Such an evaluation is common even for those ideation speeches that combine initial strategies aimed at rational reasoning, such as informative and informative-persuasive sub-strategies, with elements of emotional contamination used for creation of a positive or negative emotional background.

For instance, the ideation speech "How great leaders inspire action" by Simon Sinek (Sinek, 2010), that is one of 8 absolutely communicatively successful ideation speeches, is full of rational strategy of explanation expressed in the means of multimodality, particularly drawing charts on the board during the presentation. The same speech is filled with rational-emotional rhetoric questions addressed to the audience. Persuasion happens when the ideator puts well-known facts in a new perspective that creates an effect of a paradox. One of the examples of that is the

Table 2

Delayed responsive actions of the recipients of absolutely communicatively successful ideation speeches

\begin{tabular}{|c|c|c|c|c|c|c|c|c|c|c|c|c|c|c|c|}
\hline 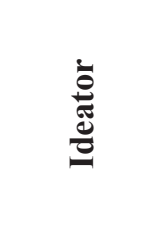 & 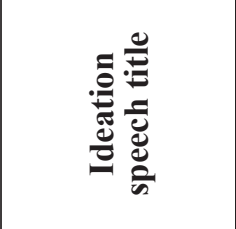 & 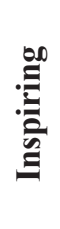 & 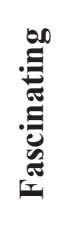 & 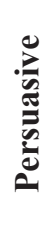 & 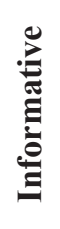 & 哭 & 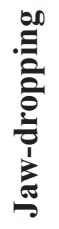 & 离 & 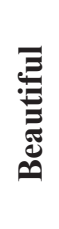 & 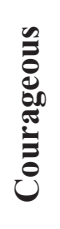 & $\frac{1}{0}$ & 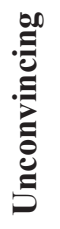 & 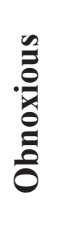 & ن & 常 \\
\hline $\begin{array}{l}\text { Brown } \\
\text { Brené }\end{array}$ & $\begin{array}{l}\text { The power of } \\
\text { vulnerability }\end{array}$ & 36 & 8 & 6 & 8 & 2 & 3 & 9 & 13 & 14 & 1 & 0 & 0 & 0 & 0 \\
\hline $\begin{array}{l}\text { Cuddy } \\
\text { Amy }\end{array}$ & $\begin{array}{l}\text { Your body } \\
\text { language } \\
\text { may shape } \\
\text { who you are }\end{array}$ & 32 & 17 & 9 & 15 & 2 & 5 & 1 & 5 & 10 & 2 & 1 & 0 & 0 & 1 \\
\hline $\begin{array}{l}\text { Robinson } \\
\text { Ken }\end{array}$ & $\begin{array}{l}\text { Do schools } \\
\text { kill creativity? }\end{array}$ & 26 & 11 & 11 & 8 & 6 & 5 & 21 & 5 & 3 & 1 & 0 & 0 & 0 & 0 \\
\hline $\begin{array}{l}\text { Sinek } \\
\text { Simon }\end{array}$ & $\begin{array}{l}\text { How great } \\
\text { leaders inspire } \\
\text { action }\end{array}$ & 38 & 13 & 16 & 12 & 6 & 5 & 1 & 3 & 2 & 2 & 2 & 0 & 0 & 1 \\
\hline $\begin{array}{l}\text { Treasure } \\
\text { Julian }\end{array}$ & $\begin{array}{l}\text { How to speak } \\
\text { so that people } \\
\text { want to listen }\end{array}$ & 23 & 10 & 15 & 30 & 4 & 1 & 5 & 4 & 2 & 4 & 1 & 0 & 0 & 0 \\
\hline $\begin{array}{l}\text { Urban } \\
\text { Tim }\end{array}$ & $\begin{array}{l}\text { Inside the mind } \\
\text { of a master } \\
\text { procrastinator }\end{array}$ & 20 & 8 & 8 & 11 & 9 & 2 & 33 & 3 & 5 & 1 & 0 & 0 & 0 & 0 \\
\hline $\begin{array}{l}\text { Veitch } \\
\text { James }\end{array}$ & $\begin{array}{l}\text { This is what } \\
\text { happens when } \\
\text { you reply to } \\
\text { spam email }\end{array}$ & 3 & 8 & 1 & 3 & 14 & 2 & 62 & 2 & 2 & 1 & 1 & 0 & 0 & 0 \\
\hline $\begin{array}{l}\text { Waldinger } \\
\text { Robert }\end{array}$ & $\begin{array}{l}\text { What makes } \\
\text { a good life? } \\
\text { Lessons from } \\
\text { the longest } \\
\text { study on } \\
\text { happiness }\end{array}$ & 40 & 12 & 8 & 14 & 1 & 1 & 1 & 18 & 2 & 1 & 1 & 0 & 0 & 1 \\
\hline
\end{tabular}


idea itself: "People don't buy what you do; people buy why you do it". It is implied that people are more likely to buy an idea that is behind some goods than goods per se:

Here's how Apple actually communicates. "Everything we do, we believe in challenging the status quo. We believe in thinking differently. The way we challenge the status quo is by making our products beautifully designed, simple to use and user friendly. We just happen to make great computers. Want to buy one?" Totally different, right? You're ready to buy a computer from me. I just reversed the order of the information. What it proves to us is that people don't buy what you do; people buy why you do it (Sinek, 2010).

There is a considerable number of explicit and implicit imperative appeals that signifies communicative influence on volitional sphere of consciousness. Successful combination of rational-emotional and volitional influence is suggested by the data: $38 \%$ of the recipients picked inspiring and 16\% chose persuasive as the most prominent characteristics of this speech. In total $54 \%$ of votes qualified this ideation speech as one that succeeds in emotional-volitional impact on the audience.

2) Ideation speeches are evaluated as persuasive (emotional-volitional impact) usually in cases if they are also characterized as informative (rational impact) with the bigger percentage share of the latter. It can be explained by the fact that when the ideator succeeds in rational informative influence with providing new useful information, persuasion on emotional level happens at the same time, though it is less noticeable. On watching the ideation speech "How to speak so that people want to listen" by Julian Treasure (Treasure 2013) most of the recipients' votes were given to the characteristic informative that complies with the format of the speech, where the ideator lists the mistakes that makes effective communication harder and ways how to keep the listener's attention. The ideator presents the audience with practical recommendations and even with a set of exercises for voice warming up. As the result, the recipients mark this ideation speech as informative.

3) Characteristic funny has either indices of dominant (from $51 \%$ to $100 \%$ ) or strong (from $33 \%$ to $50 \%$ ) communicative influence, or index of insignificant influence (to $15 \%$ ). Only 25 ideation speeches out of all 202 speeches, that are used as the material for this research, have more than $15 \%$ of votes given to this characteristic. Among these 25 speeches 8 ideation speeches have got indices of strong (4 speeches) or dominant (4 speeches) influence. This analysis indicates that if the ideator decides to use humour in their speech, serious key of the speech will be changed to humorous key and vice versa throughout the whole ideation speech. It will be reflected the recipients rating this ideation speech as funny. In rare cases practically the whole speech can be in humorous key. This is certainly true in the case of James Veitch's "This is what happens when you reply to spam email" (Veitch 2015) that is one of the absolutely communicatively successful ideation speeches. This speech consists of 2 humorous narratives that are interrupted with serious key when the ideator explains the motives for his idea, explicates it and methods of its implementation. Only 40 seconds out of total 9 minutes 20 seconds are in serious key, the rest is humour. Therefore, it is no surprise that $62 \%$ of the recipients have decided that this ideation speech is funny.

\section{Conclusion}

This study opens perspectives for the further investigation of other discourses that come to existence due to the development of the Internet technologies; consideration of the communicants' charisma as an important factor influencing communicative success of the speaker; detailing the role of the communicants' non-verbal actions (facial expressions, gestures, prosody) in exercising communicative influence.

\section{BIBLIOGRAPHY}

Бахтин М. М. Эстетика словесного творчества / Сост. С. Г. Бочаров; Текст подгот. Г. С. Бернштейн и Л. В. Дерюгина; Примеч. С. С. Аверинцева и С. Г. Бочарова. М. : Искусство, 1979. 424 с.

Выготский Л. С. Мышление и речь. изд. 5, испр. Москва : Лабиринт, 1999. 352 с.

Гуссерль Э. Логические исследования. Москва : ДИК, 2001. 1076 с.

Кайсіна Д. М. Англомовний дискурс ідеації: стратегії комунікативного впливу (на матеріалі інтернет-платформи TED): дис. ... канд. філол. наук : 10.02.04. Харків, 2018. 318 с.

Как нарисовать портрет птицы: методология когнитивно-коммуникативного анализа языка : кол. монография / Е. В. Бондаренко, А. П. Мартынюк, И. Е. Фролова, И. С. Шевченко / под. ред. И. С. Шевченко. Харьков : ХНУ имени В. Н. Каразина, 2017. $-246 \mathrm{c}$.

Мартынюк А. П. Несоответствие норме как источник смехового эффекта в тексте англоязычного анекдота // Записки 3 романо-германської філології. 2008. Вип. 20. Одеса : Фенікс. С. 80-89.

Шевченко И. С. Эволюционные механизмы когнитивной семантики // Когниция, Коммуникация, Дискурс : междунар. электронный сб. науч. ст. 2016. No 13. С. 131-141. URL: https://sites.google.com/site/ cognitiondiscourse/vypusk-no13-2016/ sevcenko-i-s.

Anderson C. TED talks : the official TED guide to public speaking. Boston : Houghton Mifflin Harcourt, 2016. 288 p.

Brown Brené. The power of vulnerability [Electronic resource] - Access: https://www.ted.com/talks/brene_brown_on_vulnerability.

Cuddy Amy. Your body language may shape who you are [Electronic resource] - Access: https://www.ted.com/talks/amy_cuddy_ your_body_language_shapes_who_you_are. 
Graham D., Bachmann T. T. Ideation: The birth and death of ideas. Hoboken, NJ : John Wiley \& Sons, 2004. 240 p.

Herr Hugh. The new bionics that let us run, climb and dance [Electronic resource] - Access: https://www.ted.com/talks/hugh_herr_ the_new_bionics_that_let_us_run_climb_and_dance.

Martynyuk A. "Now that the magic is gone" or toward cognitive analysis of verbal/co-verbal communication // Когниция, коммуникация, дискурс : междунар. электронный сб. науч. ст. No 15. С. 51-72. URL: https://sites.google.com/site/cognitiondiscourse/ vypusk-no15-2017/martynyuk-a-p.

Oliver Jamie. Teach every child about food [Electronic resource] - Access: https://www.ted.com/talks/jamie_oliver.

Robbins Tony. Why we do what we do [Electronic resource] - Access: https://www.ted.com/talks/tony_robbins_asks_why_we_ do_what_we_do.

Robinson Ken. Do schools kill creativity? [Electronic resource] - Access: https://www.ted.com/talks/ken_robinson_says_schools_ kill_creativity.

Sinek Simon. How great leaders inspire action [Electronic resource] - Access: https://www.ted.com/talks/simon_sinek_how_ great_leaders_inspire_action.

TED: Ideas worth spreading. [Electronic resource] - Access: https://www.ted.com.

Treasure Julian. How to speak so that people want to listen [Electronic resource] - Access: https://www.ted.com/talks/julian treasure_how_to_speak_so_that_people_want_to_listen.

Urban Tim. Inside the mind of a master procrastinator [Electronic resource] - Access: https://www.ted.com/talks/tim_urban_ inside the mind of a master procrastinator.

Veitch James. This is what happens when you reply to spam email [Electronic resource] - Access: https://www.ted.com/talks/ james_veitch_this_is_what_happens_when_you_reply_to_spam_email.

Waldinger Robert. What makes a good life? Lessons from the longest study on happiness [Electronic resource] - Access: https://www.ted.com/talks/robert_waldinger_what_makes_a_good_life_lessons_from_the_longest_study_on_happiness.

\section{REFERENCES}

Anderson, C. (2016). TED talks : the official TED guide to public speaking. Boston : Houghton Mifflin Harcourt.

Bahtin, М. (1979). Estetika slovesnogo tvorchestva [Эстетика словесного творчества]. Moscow : Iskusstvo.

Brown, B. (2010). The power of vulnerability [Electronic resource] - Access: https://www.ted.com/talks/brene_brown_on_ vulnerability.

Cuddy, A. (2012). Your body language may shape who you are [Electronic resource] - Access: https://www.ted.com/talks/amy_ cuddy_your_body_language_shapes_who_you_are.

Graham, D., Bachmann, T. T. (2004). Ideation: The birth and death of ideas. Hoboken, NJ : John Wiley \& Sons.

Herr, H. (2014). The new bionics that let us run, climb and dance [Electronic resource] - Access: https://www.ted.com/talks/ hugh_herr_the_new_bionics_that_let_us_run_climb_and_dance.

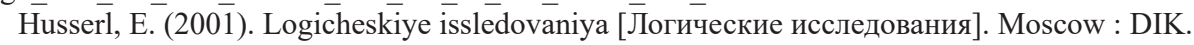

Kak narisovat portret ptytsy : metodologiya kognitivno-kommunikativnogo analiza yazyka [Как нарисовать портрет птицы: методология когнитивно- коммуникативного анализа языка]. (2017). Kharkov : KhNU imeni V. N. Karazina.

Kaysina, D. (2018). English ideation discourse: strategies of communicative influence (based on TED Internet platform). PhD. V. N. Karazin Kharkiv National University.

Martynyuk, A. (2008). Nesootvetstvie norme kak ustochnik smehovogo efekta v tekste angloyazychnogo anekdota [Несоответствие норме как источник смехового эффекта в тексте англоязычного анекдота] // Zapysky z romano-hermanskoi filolofii [Записки з романо-германської філології]. 20, p. 80-89.

Martynyuk, A. (2017). "Now that the magic is gone" or toward cognitive analysis of verbal/co-verbal communication // Kognitsia, kommunikatsia, diskurs [Когниция, коммуникация, дискурс]. 15, p. 51-72. URL: https://sites.google.com/site/cognitiondiscourse/ vypusk-no15-2017/martynyuk-a-p.

Oliver, J. (2010). Teach every child about food [Electronic resource] - Access: https://www.ted.com/talks/jamie_oliver.

Robbins, T. (2006). Why we do what we do [Electronic resource] - Access: https://www.ted.com/talks/tony_robbins_asks_why_ we_do_what_we_do.

Robinson, K. (2006). Do schools kill creativity? [Electronic resource] - Access: https://www.ted.com/talks/ken_robinson_says_ schools_kill_creativity.

Shevchenko, I. (2016). Evolutionnye mehanizmy kognitivnoy semantiki [Эволюционные механизмы когнитивной семантики]. [Electronic resource] - Access: https://sites.google.com/site/ cognitiondiscourse/vypusk-no13-2016/sevcenko-i-s.

Sinek, S. (2010). How great leaders inspire action [Electronic resource] - Access: https://www.ted.com/talks/simon_sinek_how_ great_leaders_inspire_action.

TED (2019). Ideas worth spreading. [Electronic resource] - Access: https://www.ted.com.

Treasure, J. (2013). How to speak so that people want to listen [Electronic resource] - Access: https://www.ted.com/talks/julian_ treasure how to_speak_so_that people_want_to listen.

Urban, T. (2016). Inside the mind of a master procrastinator [Electronic resource] - Access: https://www.ted.com/talks/tim_urban inside the mind_of_a master_procrastinator.

Veitch, J. (2015). This is what happens when you reply to spam email [Electronic resource] - Access: https://www.ted.com/talks/ james_veitch_this_is_what_happens_when_you_reply_to_spam_email.

Vygotsky, L. (1999). Myshleniye i rech [Мышление и речь]. Moscow : Labirint.

Waldinger, R. (2015). What makes a good life? Lessons from the longest study on happiness [Electronic resource] - Access: https://www.ted.com/talks/robert_waldinger_what_makes_a_good_life_lessons_from_the_longest_study_on_happiness. 


\begin{abstract}
Анотація
Стаття присвячена визначенню та опису респонсивних стратегій, реалізованих суб'єктами англомовного дискурсу ідеації. Англомовний дискурс ідеації є процесом і результатом взаємодії комунікантів у соціально-культурному контексті публічної промови. Суб’єктами цього дискурсу є ідеатор та реципієнт(-и), які здійснюють когнітивно-комунікативну діяльність, змістом якої $є$ прийняття та втілення ідеї, яка є об'єктом цієї взаємодії. Ідея $є$ ментальною структурою, яка втілюється вербальними та невербальними засобами комунікації. Глобальний соціально значущий комунікативний намір ідеатора полягає у здійсненні комунікативного впливу на реципієнтів з метою втілення у соціальну практику ідеї промови. Ця мета досягається через ініціальні комунікативні стратегії інформування, переконування та спонукання, яким підпорядковуються субстратегії: інформативні, інформативно-персуазивні, персуазивні, персуазивно-спонукальні і спонукальні. Субстратегії спрямовуються на різні сфери свідомості реципієнтів - раціональне мислення (інформативні, інформативно-персуазивні), емоції (персуазивні), волевиявлення (спонукальні) - або на підсвідомість (персуазивно-спонукальні). Респонсивні комунікативні дії реципієнтів поділяються на миттєві (вербальні: вигуки, короткі відповіді; невербальні: сміх, оплески, жести) і відстрочені (вербальні: кваліфікація ідеаційної промови за допомогою трьох з чотирнадцяти запропонованих прикметників позитивної / негативної оцінки; невербальні: загальна та середньомісячна кількість переглядів відео ідеаційної промови). Наукова цінність дослідження полягає у з'ясуванні конститувних рис нового об'єкта лінгвістичного аналізу англомовного дискурсу ідеації й з'ясуванні його конститутивних рис із застосуванням інференційного аналізу, який дозволяє виявити стратегії раціонального, емотивного, орієнтованого на волевиявлення комунікативного впливу та відповідних цьому впливу респонсивні стратегії, втілювані у вербальних і невербальних діях суб’єктів дискурсу.
\end{abstract}

\title{
Ключові слова
}

Англомовний дискурс ідеації, волевиявлення, емоції, ініціальна стратегія, комунікативний вплив, раціональне мислення, респонсивна стратегія. 